RESEARCH ARTICLE

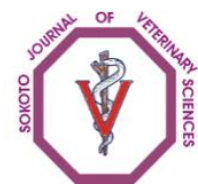

Sokoto Journal of Veterinary Sciences

(P-ISSN 1595-093X/E-ISSN 2315-6201)

Jimoh et al/Sokoto Journal of Veterinary Sciences (2014) 12(2): 19-24.

http://dx.doi.org/10.4314/sokjvs.v12i2.4

\title{
Microbial flora of the gastro-intestinal tract of Clarias gariepinus caught from river Dandaru Ibadan, Nigeria
}

\author{
WA Jimoh ${ }^{1}$, MO Oladele-Bukola ${ }^{2}$, MD Adebayo ${ }^{3}$, AA Yusuff $^{4}$, FA Azeez $^{3} \& O O$ \\ Salami ${ }^{4}$
}

1. Department of Fisheries Technology, Federal College of Animal Health and Production Technology, PMB 5029, Ibadan, Nigeria

2. Department of Livestock Improvement Programme, Institute of Agricultural Research and Training, Ibadan, Nigeria.

3. Department of Animal Health, Federal College of Animal Health and Production Technology, Moor Plantation, PMB 5029, Ibadan, Nigeria

4. Science Laboratory Department, Federal College of Animal Health and Production Technology, PMB 5029, Ibadan, Nigeria

*Correspondence: Tel.:2348062287099, E-mail:jawabus@gmail.com

\section{Abstract}

The study reports the microbial load and diversity in the gastro-intestinal tract of Clarias gariepinus caught in River Dandaru, Ibadan. A set of adult samples of Clarias gariepinus was caught from the river Dandaru, Ibadan. Determination of microbial loads and characterization of microorganisms present in the gut region of the captured Clarias gariepinus were carried out using standard microbiological procedures. The fungi isolated were Aspergillus niger, Aspergillus flavus, Penicillium atrovenetum and Penicillium expansum while the bacteria isolated were Pseudomonas fluorescens, Bacillus alvei, Aeromonas hydrophilia, Bacillus megaterium, Flavobacterium rigense and Enterobacter aerogenes. The microbial counts were; total plate count $6.5 \times 10^{5} \mathrm{CFUs} / \mathrm{g}$, total coliform count 1.9 $\times 10^{4} \mathrm{CFUs} / \mathrm{g}$, total anaerobic count $4.2 \times 10^{2} \mathrm{CFUs} / \mathrm{g}$, total faecal coliform count was $2.2 \times 10^{3} \mathrm{CFU} / \mathrm{ml}$, total fungi count $3.0 \times 10^{3}$ spore/g.

Keywords: Microbial Load,Catfish gut, Microbial diversity, River Dandaru

Received: 06-01-2014

Accepted: 12-05-2014

\section{Introduction}

Several species of bacteria and fungi were found to be associated with fish species (Lio-Po et al., 1992). Parasites and diseases, which are caused by the presence of pathogenic microbial flora, reduce fish production by affecting the normal physiology of fish (Kabata, 1985) and which, if left uncurtailed, can result in mass mortalities of fish, or in some cases, infection of man and other vertebrates that consume them (Shawn, 1997). The gut flora consists of the microorganisms that normally live in the digestive tract of animals (O'Hara \& Shanahan, 2006). Bacteria, including the non pathogenic and pathogenic, are usually present in small numbers in most fish and in normal situation seldom cause any problem as the fish possess adequate immune system capable of fending off infections (Shawn, 1997). There is paucity of information on gut microflora in fish (Mondal et al., 2008). Nigeria is the highest producer of Clariid catfish in the world (Williams et al., 2007). The microorganisms present in the gut perform a host of functions such as fermenting unused energy substrates, training the immune system, preventing growth of harmful species (Guarner \& Malageladar, 2003a; Sears, 2005), regulating the development of the gut and producing vitamins for the host. However, in certain conditions some species are thought to be capable of causing disease by causing infection to the host. (Guarner \& Malageladar, 2003b; Beaugerie \& Petit, 2004). In the present study, an attempt has been made to investigate the microflora of the gut of captured Clarias gariepinus.

\section{Materials and methods}


Collection of specimen

Twelve $250 \pm 5.8 \mathrm{~g}$ of Clarias gariepinus were collected from fishermen at river Dandaru, Ibadan, Oyo state, Nigeria. The samples collected from the wild were visually examined and confirmed to be apparently healthy.

\section{Dissection of the specimens}

Each of the specimens was dissected aseptically to remove the gut (the entire alimentary canal). The glasswares were sterilized in an oven at $160{ }^{\circ} \mathrm{C}$ for 90 minutes. Absolute alcohol was used to sterilize the surface of the working table. The gastro-intestinal tract of each sample was cut into fore-gut, hind-gut and mid-gut.

\section{Isolation and characterization of microflora}

Each organ was placed in sterile bottle containing $5 \mathrm{ml}$ sterile distilled water and vigorously shaken to allow the content to dissociate in water. Then from each suspension $0.1 \mathrm{ml}$ was pour plated, using freshly prepared Sabouraud Dextrose Agar medium (SDA). The plates after being covered were gently swirled to evenly mix up and allowed to gel. The plates were allowed to stay in the inoculating chamber for $3-4$ days. Representative colonies emerging from the plates were grouped according to their cultural characteristics, purified by repeated sub-culturing and maintained on appropriate agar slants as stock culture. Microscopic examination of young, actively growing moulds was on the basis of structures bearing spores and on the spore themselves; presence or absence of septation, rhizoid or other tissues. The microbial isolates were identified by their micro-morphology as well as the colour and micro-morphology of their sporulating structures and conidia according to Onions et al. (1981). For bacteria count and isolation, the gastro-intestinal tract (GIT) of each sample was placed in sterile bottle containing $5 \mathrm{ml}$ sterile distilled water and vigorously shaken to allow the content to dissociate in water. $1 \mathrm{ml}$ was taken and serially diluted to $10^{-6}$. Microbial load determination, isolation and characterization of microorganisms using serial dilution and pour plate method were carried out using nutrient agar. Representative colonies emerging from the plates after incubation at $37^{\circ} \mathrm{C}$ for 24hours were grouped according to their cultural characteristics, purified by repeated sub-culturing and maintained on appropriates agar slants as stock cultures. The bacterial isolates were tested for Gram reaction (Claus, 1992), morphology, motility, catalase and oxidase reactions, citrate utilization, coagulase production, starch hydrolysis and sugar fermentation (Seeley \& Van Demark 1972; Harrigan \& McCance, 1976). The resultant colonies were characterized and identified using the criteria of Holt et al. (1994).

\section{Microbial count}

Bacteria colonies which developed after incubation were subjected to counting and were expressed in Colony Forming Unit (CFU)/g and CFU/ml for faecal coliform count. The total fungal counts were expressed as spore/g.

\section{Results}

Table 1 shows the microbial count of clariid catfish caught from river Dandaru, Ibadan. The total plate count was $6.5 \times 10^{5} \mathrm{CFUs} / \mathrm{g}$, Total coliform count was $1.9 \times 10^{4} \mathrm{CFUs} / \mathrm{g}$, total anaerobic count was $4.2 \times 10^{2}$ CFUs/g, Total faecal coliform count was $2.2 \times 10^{3}$ $\mathrm{CFU} / \mathrm{ml}$. Total Fungi Count was $3.0 \times 10^{3} \mathrm{spore} / \mathrm{g}$. Table 2 shows the results of morphological and biochemical tests used in identifying bacteria isolates from the gastro-intestinal tract of clarrid catfish caught from river Dandaru, Ibadan. The bacteria isolates were Pseudomonas fluorescens, Bacillus alvei, Bacillus licheniformis, Aeromonas hydrophilia, Bacillus megaterium, Flavobacterium rigense and Enterobacter aerogenes. The identification of fungi isolates from the gastrointestinal tract of clariid catfish caught from river Dandaru, Ibadan is presented in table 3. The isolated fungi were Aspergillus niger, Aspergillus flavus, Penicillium atrovenetum and Penicillium expansum.

Table 1: Microbial count in the gastrointestinal tract of clariid catfish caught from river Dandaru, Ibadan

\begin{tabular}{lll}
\hline & Parameters & Count \\
\hline Bacteria Count & Total plate count & $6.5 \times 10^{5}$ \\
(CFU/g) & Total coliform count & $1.9 \times 10^{4}$ \\
& Total anaerobic count & $4.2 \times 10^{2}$ \\
(CFU/ml) & Total faecal coliform count & $2.2 \times 10^{3}$ \\
Fungi Count (Spore/g) & Total fungi count & $3.0 \times 10^{3}$ \\
\hline
\end{tabular}


Table 2: Identification of bacteria isolates from the gastrointestinal tract of Clariid catfish caught from river Dandaru, Ibadan

\begin{tabular}{|c|c|c|c|c|c|c|c|c|}
\hline \multicolumn{2}{|l|}{ Parameters } & 1 & 2 & 3 & 4 & 5 & 6 & 7 \\
\hline \multicolumn{2}{|l|}{ Gram Reaction } & - & - & - & + & + & - & - \\
\hline \multicolumn{2}{|l|}{ Cell Morphology } & $\mathrm{R}$ & $\mathrm{R}$ & $\mathrm{R}$ & $\mathrm{R}$ & $\mathrm{R}$ & $\mathrm{R}$ & $\mathrm{R}$ \\
\hline \multicolumn{2}{|l|}{ Catalase } & + & + & + & + & + & + & + \\
\hline \multicolumn{2}{|l|}{ Oxidase } & + & + & - & + & + & - & - \\
\hline \multicolumn{2}{|l|}{ Casein Hydrolysis } & + & + & + & + & + & - & - \\
\hline \multicolumn{2}{|l|}{ Gelatin Hydrolysis } & + & + & + & + & + & + & $(+)$ \\
\hline \multicolumn{2}{|l|}{ Starch Hydrolysis } & - & - & - & + & $(+)$ & - & - \\
\hline \multicolumn{2}{|l|}{ Methyl Red } & + & + & + & - & - & - & - \\
\hline \multicolumn{2}{|l|}{ Voges-Proskair } & + & + & + & - & - & - & + \\
\hline \multicolumn{2}{|l|}{ Nitrate Reduction } & - & - & - & + & + & + & - \\
\hline \multirow[t]{2}{*}{ Growth } & $60^{\circ} \mathrm{C}$ & + & - & - & - & - & - & - \\
\hline & $30^{\circ} \mathrm{C}$ & + & + & - & - & - & + & - \\
\hline \multicolumn{2}{|l|}{ Coagulase } & + & + & + & - & - & - & + \\
\hline \multicolumn{2}{|l|}{ Urease } & - & - & - & - & - & - & d \\
\hline \multirow[t]{2}{*}{ Growth pH @ } & 3.9 & - & - & - & - & $(+)$ & - & - \\
\hline & 9.2 & + & + & + & + & + & + & + \\
\hline Growth $\mathrm{NaCl}$ & & $(+)$ & $(+)$ & - & + & + & - & - \\
\hline Citrate Utilisation & & + & - & - & + & - & - & \\
\hline Motility & & + & + & + & + & + & + & + \\
\hline Indole Test & & - & + & + & - & - & - & - \\
\hline Glucose & & + & $+\mathrm{G}$ & + & $+\mathrm{G}$ & $+\mathrm{G}$ & + & + \\
\hline Fructose & & - & - & + & + & + & + & + \\
\hline Maltose & & - & + & + & + & + & + & + \\
\hline Lactose & & - & + & $(+)$ & + & $(+)$ & + & + \\
\hline Sucrose & & + & + & $d$ & + & $(+)$ & + & + \\
\hline Galactose & & $d$ & $(+)$ & $d$ & $(+)$ & + & - & + \\
\hline Xylose & & $(+)$ & - & + & + & + & - & + \\
\hline Arabinose & & - & - & - & + & + & $(+)$ & + \\
\hline Raffinose & & + & $(+)$ & d & - & - & - & + \\
\hline Rhamnose & & + & - & - & - & + & - & + \\
\hline Dulcitol & & - & $(+)$ & - & + & - & - & + \\
\hline Mannitol & & + & - & + & + & - & + & + \\
\hline $\begin{array}{l}\text { Probable bacteria } \\
\text { isolate }\end{array}$ & & $\begin{array}{l}\text { Pseudomona } \\
\text { fluorescens }\end{array}$ & $\begin{array}{l}\text { Bacillus } \\
\text { alvei }\end{array}$ & $\begin{array}{l}\text { Aeromonas } \\
\text { hydrophila }\end{array}$ & $\begin{array}{l}\text { Bacillus } \\
\text { megaterium }\end{array}$ & $\begin{array}{l}\text { Bacillus } \\
\text { licheniformis }\end{array}$ & $\begin{array}{l}\text { Flavobacterium } \\
\text { rigense }\end{array}$ & $\begin{array}{l}\text { Enterobacter } \\
\text { aerogenes }\end{array}$ \\
\hline
\end{tabular}


Table 3: Identification of fungi isolates from the gastrointestinal tract of Clariid catfish caught from river Dandaru, Ibadan

\begin{tabular}{|c|c|c|c|}
\hline $\mathrm{S} / \mathrm{N}$ & Spore conidia under microscope & Cultural characteristics & Probable fungi isolated \\
\hline 1. & $\begin{array}{l}\text { Conidia are large with radiating heads, } \\
\text { mostly globose and irregularly } \\
\text { roughed. }\end{array}$ & $\begin{array}{l}\text { Powdery black conidiosphores arising } \\
\text { from long, broad thick-walled, } \\
\text { sometimes branched foot cells, it has } \\
\text { tall conidiophores. }\end{array}$ & Aspergillus niger \\
\hline 2. & $\begin{array}{l}\text { Conidia react radiating a large number } \\
\text { of metulae support the phialide } \\
\text { conidia is globose, finely roughed. }\end{array}$ & $\begin{array}{l}\text { It is characteristically yellow, green } \\
\text { conidiosphores hyaline and rough } \\
\text { walled }\end{array}$ & Aspergillus flavus \\
\hline 3. & $\begin{array}{l}\text { penicillin typically with an additional } \\
\text { divergent branch conidia globose and } \\
\text { coarsely wartly. }\end{array}$ & $\begin{array}{l}\text { Colonies growing restrictedly with } \\
\text { bright bluish-green, later deep greyish } \\
\text { blue conidial aerial; reveres the } \\
\text { pigment diffusing into agar } \\
\text { conidiophore partly rough walled. }\end{array}$ & Penicillium atrovenetum \\
\hline 4. & $\begin{array}{l}\text { Penicillin } 2-3 \text { staged branched with } \\
\text { numerous usually oppressed metulae, } \\
\text { conidia sub globose to ellipsoidal, } \\
\text { smooth-walled with aromatic odour, } \\
\text { fruity and suggesting apples }\end{array}$ & $\begin{array}{l}\text { Colonies fast growing conidiosphores } \\
\text { in fresh isolated typically loosely } \\
\text { symematous, giving the colony a } \\
\text { zonate appearance colonies are light } \\
\text { green, reverse colorless yellow-brown } \\
\text { conidiophores are smooth-walled. }\end{array}$ & Penicillium espansum \\
\hline
\end{tabular}

\section{Discussion}

The microflora isolated in the gut of captured Clarias gariepinus were similar to those of Jimoh et al (2009 a) and Jimoh et al (2009b) plausibly related to what is obtainable from their environment. Strom and Olafsen (1990) reported that bacteria are abundant in the environment in which fish live and it is therefore impossible to avoid them being a component of their diet. The bacteria entering along with the diet of fish during ingestion may adapt themselves in the gastro intestinal tract and form a symbiotic association within the digestive tract of fish in which large numbers of microbes are present (Trust et al., 1979; Rimmer \& Wiebe 1987; Ringo \& Strom 1994; Clements \& Choat 1995) which is much higher than in the surrounding water indicating that the digestive tracts of fish provide favorable ecological niches for these organisms(Trust and Sparrow1974; Sakata 1990).Representatives of 25 bacteria genera have been reported as pathogens of freshwater or marine fish (Cameron, 2002). In the present study, the microbial load in the gut of captured Clarias gariepinus reported is in agreement with earlier work by Mondal et al. (2008). Buras et al. (1987) reported that in general fish usually contain high numbers of bacteria (including pathogenic micro-organisms; Pseudomonas, Aeromonas, Salmonella etc.) in the digestive tract, gills and flesh. The bacteria isolated in the gastrointestinal tract of catfish were Pseudomonas fluorescens, Bacillus spp, Aeromonas hydrophila, Flavobacterium rigense, Enterobacter aerogenes, Bacillus licheniformiis, Pseudomonas aeruginosa,. Haniffa and Abdulkader (2011) reported that bacteria especially motile aeromonads are frequently isolated from both healthy and diseased fish as well as from other aquatic animals. Pseudomonas and Flavobactrium have been implicated in spoilage of fish and Aspergillus is associated with disease outbreak in fish (Alabi, 1989; Okaeme et al 1988; Olayemi et al 1990). The results of this study indicated that microflora can be obtained from the gastro intestinal tract of catfish which may not only be pathogenic to fish but when consumed by man can cause disease. 


\section{References}

Alabi RO (1989). Mycology and National Development. Mobilization of fungi products for life abundant. Inaugural Lecture 10.University of Ilorin.Pp 36.

Beaugerie L \& Petit JC (2004). Microbial gut Interaction in Health and Disease. Antibiotics associated diarrhea. Best Practice and Research clinical Gastro Enterology, 18(2): 337- 352.

Buras N, Duek L, Niv S, Hepher B and Sandbank E. (1987). Microbiological aspects of fish grown in treated waste water. Water Research, 21(1):1-10.

Cameron A (2002). Survey Toolbox for Aquatic Animal Disease. A Practical Manual and Software Package. Australian Centre for International Agriculture research, Canberra, Pp 375.

Claus D (1992). A standardized gram-staining procedure. Journal of Microbiolology and Biotechnology, 8(4):451-452.

Clements KD \& Choat JH (1995). Fermentation in tropical marine herbivorous fishes. Physiology and Zoology, 68(3):355-378.

Guarner F \& Malagelada JR (2003a): Gut flora in Health and Disease. The Lancet, 361 (9356): 512- 519.

Guarner F \& Malagelada JR (2003b). Role of bacteria in experimental colitis.17 (5): 793-804.

Haniffa MA \& AbdulKader KP (2011). Haematological changes in Channa striatus experimentally infected by Aeromonas hydrophila. Bioresource Bulletin, 1(4): 246-253.

Harrigan WF \& McCance ME (1976). Laboratory methods in food and dairy microbiology. Academic press, London, Pp 452

Holt JG, Krieg NR, Sneath PH, Staley JT \& Williams ST (1994). Bergey's manual of determinative bacteriology, 9th edition. Baltimore, Md: The Williams \& Wilkins Co, Pp 787.

Jimoh WA, Jabar MB, Adeleke MA \& Bello BK (2009a). Diversity and microbial load of fungi isolates of the gut sections of captured and cultured Clarias gariepinus in Abeokuta, South Western Nigeria. Journal of Field Aquatic Studies, 5:54-60.

Jimoh WA, Jabar MB, Adeleke MA \& Bello BK (2009b). Bacterial isolates in the different gut regions of captured and cultured Clarias gariepinus in Abeokuta North Local Government. Nigerian Journal of Fisheries, 6(1\&2): 63-70.
Kabata Z (1985). Parasites and diseases of fish cultured in the tropics. Taylor and Francis publication, London, Pp 92- 107.

Lio-Po GD, Albright $\amalg$ \& Alapide-Tendencia EV (1992). Aeromonas hydrophila in the epizootic ulcerative syndrome (EUS) of snakehead (Ophicephalus striatus) and catfish (Clarias batrachus): Quantitative estimation in natural infection and experimental induction of dermo-muscular necrotic lesion. In: Diseases in Asian aquaculture I. Fish Health Section Shariff $M$, Subasinghe RP, Arthur JR, editors), Asian Fisheries Society Manila, Pp 461-474.

Mondal S, Roy T, Sec SK \& Ray AK (2008). Distribution of enzyme-producing bacteria in the digestive tracts of some freshwater fish. Acta Ichthyologica Piscatoria, 38(1):1-8.

O'Hara AM \& Shanahan F (2006). The gut flora as a forgotten organ. EMBO Report 7(7):688693.

Okaeme AN, Obiekezie Al, Lehman J, Antai EE, \& Madu CT (1988). Parasites and Diseases of Cultured Fish of Lake Kainji Area. Nigeria. Journal of fish Biology, 32: 479-481.

Olayemi AB, Adedayo O \& Ojo AO (1990). Microbiological studies on freshwater fishes from the Asa River, Ilorin, Nigeria. Journal of Aquaculture in the Tropics, 5: 139-139.

Onions AHS, Allsopp D \& Eggins HOW (1981). Smiths Introduction to Industrial Mycology. Edward Arnold, London, Pp 389.

Rimmer DW \& Wiebe WJ (1987). Fermentative microbial digestion in herbivorous fishes. Journal of Fish Biology, 31(): 229-236.

Ringo E \& Strom E (1994). Microflora of Arctic charr, Salvelinus alpinus (L.). I. The gastrointestinal microflora of free-living fish and the effect of diet and salinity on intestinal microflora. Aquaculture and Fisheries Management, 25: 623-629.

Sakata T (1990). Microflora in the digestive tract of fish and shell-fish. In: Microbiology in poecilotherms [sic] (Lésel R, editor). Elsevier Science, Amsterdam, Pp 171-176.

Sears CL (2005). A Dynamic Partnership: celebrating our gut flora. Anaerobe, 11(5):247- 251.

Seeley HW (Jnr) \& PJ Van Demark. (1972). Microbes in action- a laboratory manual of Microbiology. Freeman, San Francisco, Pp 361. 
Shawn P (1997). Diseases of Fish. Disease in Nature part 10 Aquarium.net Article Index (0897). http://www.reefs.org/library/aquarium_net /0897/0897_4.html, retrieved 2014-05-21.

Strom E \& Olafsen JA (1990). The indigenous microflora of wild-captured juvenile cod in net-pen rearing. In: Microbiology in poecilotherms [sic] (Lésel $R$, editor). Elsevier Science, Amsterdam, Pp 181-185.

Trust TJ \& Sparrow RAH (1974).The bacterial flora in the alimentary tract of freshwater salmonid fishes. Canadian Journal of Microbiology, 20: 1219-1228.
Trust TJ, Bull LM, Currie BR\& Buckley JT (1979). Obligate Anaerobic Bacteria in the Gastrointestinal microflora of the grass carp (Ctenopharyngodon idella), goldfish (Carassius auratus), and rainbow trout (Salmo gairdneri). Journal of Fisheries Research Board of Canada,36:1174-1179.

Williams BB, Olaosebikan BD, Adeleke A \& Fagbenro OA (2007). Status of African catfish farming in Nigeria. In: Proceedings of a workshop on the development of genetic improvement program for African catfish Clarias gariepinus held in Ghana (Raul WP \& Nguyan HN, editors) Pp 49-56. 